\title{
DAMPAK KEHADIRAN STASIUN TELEVISI BERBAHASA LOKAL PAL TV (PALEMBANG TV) PADA PELESTARIAN BAHASA LOKAL DI KOTA PALEMBANG
}

\author{
The Impact of Tv Local PAL (Palembang Tv) Television Station towards Local Language \\ Preservation in Palembang City
}

\author{
Desmalinda, Piky Herdiansyah, dan Rahmadina Naripati \\ Universitas Sriwijaya \\ Pos-el: desmalinda@yahoo.com
}

\begin{abstract}
Abstrak
Penelitian ini bertujuan untuk mendeskripsikan fungsi dan peran televisi dalam pelestarian bahasa Palembang. Adapun metode yang digunakan adalah metode deskripptif kualitatif. Data di peroleh dari wawancara langsung kepada tujuh narasumber yang berdomisisli di kota Palembang, beragam latar belakang, profesi, dan tingkat pendidikan untuk mengetahui dampak adanya televisi lokal berbahasa Palembang. Temuan penelitian ini adalah stasiun televise berjaringan nasional belum menjalankan fungsinya edukasi dan pelestarian bahasa daerah sebagaimana mestinya. Tingkat pelestarian bahasa lokal pada televise berjaringan nasional masih rendah. Kekurangan televise berjaringan ini sedikit tertutupi dengan hadirnya televise lokal, seperti PAL TV. Televisi dapat menjadi sarana strategis dalam pelestarian bahasa dengan pengelolaan yang baik berupa penambahan acara yang beragam dan sesuai dengan minat masyarakat.
\end{abstract}

Kata kunci: televisi, bahasa lokal, pelestarian

\begin{abstract}
This research aims to describe the function and role of the television in preserving Palembang language. The method used in this research is qualitative descriptive method. The data were collected from direct interviews to seven informants reside in Palembang with various backgrounds, professions and education levels to discover the impact of Palembang-speaking local television station. The research shows that national television stations have not performed their role in education and language preservation as they should be. The level of local language preservation in national television stations is still low. This condition is covered by the presence of local stations, such as PAL TV. Televisions can be a strategic tool in language preservation with proper management by adding diverse programs that are in accordance with the public interests.
\end{abstract}

Keywords: television; local language; preservation.

\section{PENDAHULUAN}

Penggunaan bahasa Indonesia sangat luas dan mencakup hampir di segala aspek mulai dari sastra, pendidikan, surat-menyurat resmi, pemerintahan, perangkat lunak, pengoprasian mesin, dan digunakan sebagai bahasa utama media massa. Sesuai dengan 
undang-undang penyiaran No. 2 Tahun 2002, Bab IV, Pasal 37, bahasa utama yang digunakan untuk menyelenggarakan program siaran oleh media siaran adalah bahasa Indonesia yang baik dan benar.

Dewasa ini perkembangan teknologi informasi sangat berpengaruh kepada masyarakat. Televisi menjadi salah satu media favorit masyarakat dari kota hingga ke pelosok. Program televisi memiliki dampak yang sangat besar kepada masyarakat. Media televisi mempunyai fungsi penting, terutama dalam penyebarluasan bahasa melalui siaran yang disediakan oleh stasiun televisi.

Bahasa Indonesia bukanlah bahasa ibu bagi sebagian besar penuturnya yang menggunakan 746 bahasa lain sebagai bahasa ibu. Namun, lebih kurang 90\% penduduk Indonesia mengerti bahasa Indonesia dengan cukup baik. Hal itu tidak lepas dari peran televisi sebagai lembaga penyiaran massal. Hal itu membuktikan bahwa media televisi mempunyai fungsi vital sebagai alat penyebarluasan bahasa.

Selain pentingnya bahasa Indonesia sebagai bahasa nasional, jangan lupakan bahasa lokal atau daerah. Banyaknya bahasa daerah yang ada di seluruh wilayah Indonesia merupakan khazanah budaya bangsa yang harus dilestarikan keberadaannya. Saat ini Indonesia memiliki lebih dari 746 bahasa daerah yang tersebar di 17.508 pulau (Budiwiyanto, 2016).

Di antara keberanekaragaman bahasa tersebut banyak di antara bahasa-bahasa daerah yang mulai ditinggalkan penuturnya dan kurang dilestarikan. Badan Pengembangan dan Pembinaan Bahasa, Kementerian Pendidikan dan Budaya mencatat 15 bahasa daerah di Indonesia telah punah dan 146 bahasa lainya dalam status terancam punah (Alwi, 2002).

Stasiun jaringan yang dimiliki oleh televisi nasional pun kurang memberi porsi bahasa lokal pada siarannya. Bahkan, beberapa televisi nasional tidak memiliki televisi berjaringan yang menyediakan konten lokal dalam acara yang disiarkannya, ditambah dengan banyaknya bahasa gaul yang ada di siaran televisi tertentu. Hal ini membuat bahasa daerah semakin dikesampingkan oleh penuturnya.

Di kota Palembang terdapat dua stasiun televisi lokal yaitu Sriwijaya TV dan PAL TV (Palembang TV). Fokus penelitian ini adalah melihat dampak penyelenggaraan penyiaran di kota Palembang khusunya pada PAL TV yang merupakan televisi lokal Palembang yang 
cenderung lebih dekat dengan masyarakat dengan $80 \%$ program acaranya mengangkat kearifan dan bahasa lokal.

PAL TV (Palembang TV) adalah sebuah stasiun televisi lokal yang bersiaran di wilayah kota Palembang dan sekitarnya. Stasiun televisi ini dapat ditemukan di channel 42 UHF (khusus Sumatera Selatan). Stasiun televisi ini merupakan anggota jaringan Jawa Pos.

Pada dasarnya televisi adalah media massa yang dimanfaatkan masyarakat guna mendapatkan informasi seputar dunia luar dan juga sebagai penghubung dengan kebijakan pemerintah. Selain itu juga, televisi merupakan sarana praktis untuk mendapatkan hiburan. Banyak sekali ragam acara televisi di antaranya program berita, sajian budaya dan seni yang dapat menarik masyarakat untuk menonton acara tersebut. (Dominick, 2012)

Menurut Undang-undang penyiaran No. 32 Tahun 2002, BAB II Pasal (IV) fungsi media massa ialah (a) sebagai media informasi, pendidikan, hiburan yang sehat, kontrol dan perekat sosial, (b) penyiaran juga mempunyai fungsi ekonomi dan kebudayaan.

Dalam UU No. 32 tahun 2002 tentang penyiaran Pasal 6 ayat (3) dikatakan bahwa stasiun televisi yang bersiaran nasional harus memiliki perwakilan televisi lokal di daerah. Peraturan tersebut mengharuskan televisi yang bersiaran nasional dan memiliki kantor pusat di kota besar seperti Jakarta dan melepaskan frekuensinya untuk dikelola oleh suatu lembaga siaran di daerah yang bersifat lokal, apabila ia ingin siaran televisinya dapat ditangkap di daerah maka ia harus bekerja sama dengan lembaga penyiaran setempat atau membuka perwakilan stasiun televisi lokal di wilayah tersebut. Stasiun televisi yang memiliki siaran nasional dan memiliki perwakilan di daerah disebut dengan stasiun televisi berjaringan nasional.

Sedangkan televisi lokal adalah stasiun televisi yang bersiaran dalam skala wilayah yang lebih kecil dan frekuensinya hanya dapat ditangkap di sekitar wilayah itu. Perbedaan televisi lokal dan televisi berjaringan nasional adalah televisi berjaringan nasional memerlukan perwakilan lembaga di daerah agar acaranya dapat ditayangkan di stasiun televisi tersebut sementara stasiun televisi lokal tidak, karena ia hanya bersiaran secara lokal dalam area terbatas di daerah (Bungin, 2006). 


\section{LANDASAN TEORI}

Media massa memiliki tiga sifat atau karakteristik yang berperan dalam membentuk opini publik (Morissan, 2013:531), yaitu (a) sifat ubikuitas, (b) sifat kumulatif, dan (c) sifat konsonan. Televisi yang mempunyai fungsi sebagai alat penyebarluasan bahasa sebetulnya dapat menjadi harapan untuk mempreservasi bahasa-bahasa daerah yang berstatus hampir punah agar tidak sampai kepada kepunahan. Kenyataanya stasiun televisi nasional yang bersiaran di daerah kurang memperhatikan hal tersebut. Memang beberapa stasiun televisi yang bersiaran di kota Palembang telah menyediakan konten berbahasa daerah, tetapi yang menjadi permasalahan adalah proporsi bahasa daerah yang sangat sedikit dan tidak efektif.

\section{METODE PENELITIAN}

Dalam penulisan penelitian ini digunakan metode deskriptif kualitatif untuk melihat bagaimana fungsi televisi sebagai alat pelestari bahasa sudah berjalan sesuai dengan rencana selain itu, bagaimana peran televisi lokal dalam membangun pelestarian bahasa lokal itu sendiri.

Data diperoleh dari wawancara langsung kepada narasumber yang berdomisili di kota Palembang untuk mengetahui bagaimana dampak adanya televisi lokal berbahasa Palembang pada masyarakat. Untuk itu diwawancarai tujuh narasumber yang berasal dari beragam latar belakang profesi dan tingkat pendidikan. Selain itu, data diperoleh dari stasiun televisi yang bersiaran di Kota Palembang dan Komisi Penyiaran Indonesia Daerah (KPID) Sumatera Selatan.

Teknik analisis data berupa analisis deskriptif kualitatif. Analisis deskriptif adalah proses pengumpulan dan penyusunan sebuah data untuk dianalisis terhadap data tersebut. Analisis deskriptif kualitatif menghasilkan data yang dikumpulkan berupa kata-kata dan bukan angka. Hal ini dikarenakan penerapan metode kualitatif dalam penelitian ini. Selain itu data yang dianalisis menjadi temuan-temuan yang menarik.

\section{HASIL DAN PEMBAHASAN}

\section{Deskripsi Hasil}

Dari data yang didapat diketahui bahwa terdapat delapan belas stasiun televisi swasta dan satu stasiun televisi publik yang bersiaran di wilayah kota Palembang. Lima belas di antaranya merupakan televisi berjaringan nasional yang memiliki perwakilan di 
kota Palembang dan empat stasiun televisi lain adalah stasiun televisi lokal yang bersiaran di kota Palembang dan sekitarnya (Mulyana, 2012).

Acara-acara yang ditampilkan oleh mayoritas stasiun televisi berjaringan nasional dianggap kurang efektif karena ditayangkan di jam-jam yang bukan merupakan waktu efektif dan aktivitas masyarakat. Banyak di antara acara tersebut ditayangkan dini hari di waktu sebagian besar masyarakat sedang beristirahat, dan porsi acaranya hanya berkisar 10\%-- 30\%. Episode tertentu diulangi kembali penayangannya sehingga membuat masyarakat relatif bosan. Sebagian masyarakat yang kami wawancarai menganggap bahwa hal tersebut dirasa kurang efektif untuk mendukung pelestarian bahasa dan kearifan lokal.

Tabel 1

Data Acara Televisi di PAL TV

Data Acara Televisi di PAL TV

\begin{tabular}{lll}
\hline Nusantara Kini $(*)(\mathrm{D})$ & PAL Online $(*)(\mathrm{R})$ & PAL KLIP $(*)(\mathrm{R})$ \\
\hline Hallo Palembang $(*)(\mathrm{D})$ & PALTV Peduli(SU) & CAWISAN $(*)(\mathrm{SU})$ \\
\hline Studio $42(*)(\mathrm{R})$ & Liputan Metropolis $(\mathrm{D})$ & TADABUR $(*)(\mathrm{SU})$ \\
\hline Documenter $(\mathrm{R})$ & Liputan SumSel $(*)(\mathrm{D})$ & \\
\hline $\begin{array}{l}\text { Tembang Batanghari }(*) \\
(\mathrm{D})\end{array}$ & Grebek $(*)(\mathrm{D})$ & \\
\hline
\end{tabular}

Sumber : www.paltv.co.id

Ket :

$(*)=$ Acara berbahasa Palembang

$(\mathrm{R})=$ Segmentasi remaja

(D) $=$ Segmentasi Dewasa

$(\mathrm{SU})=$ Segmentasi Semua Umur

Akan tetapi, hal tersebut diimbangi oleh kehadiran televisi lokal daerah yang sebagian besar programnya menampilkan bahasa dan kearifan lokal di antaranya Palembang TV (PAL TV), Sriwijaya TV, Musi TV, dan Indo Global Media (IGM TV). Di PAL TV sebagian besar acara yang ditampilkan menggunakan bahasa daerah dan menampilkan kearifan lokal budaya Palembang dengan porsi sebanyak 70\%-80\% acaranya menggunakan bahasa Palembang. Sriwijaya TV juga menampilkan acara-acara yang mengangkat kearifan dan berbahasa lokal sekitar 40\%--50\% sedangkan, untuk IGM TV tidak diperoleh datanya dan Musi TV baru menguji coba siarannya dan belum 
sepenuhnya bersiaran.

Dalam penelitian ini fokus pembahasan mengenai PAL TV karena stasiun televisi ini banyak mengangkat bahasa Palembang dan kearifan lokal pada program siarannya. Alasan tidak dibahas stasiun televisi lain (Sriwijaya TV, IGM TV, dan MUSI TV) dikarenakan beberapa hal, yaitu Sriwijaya TV hanya memiliki relatif sedikit tayangan yang berbahasa lokal, IGM TV merupakan televisi milik lembaga pendidikan yang jangkauan siarannya hanya bisa dijangkau di wilayah yang terbatas, dan MUSI TV baru menguji coba siarannya dan belum dapat ditangkap secara penuh.

Hal lain yang menjadi faktor kurang efektifnya pelestarian bahasa Palembang melalui media televisi adalah minat masyarakat terhadap tayangan televisi lokal cenderung masih kurang jika dibandingkan dengan televisi berjaringan nasional. Beberapa orang yang diwawancarai mengatakan bahwa mereka lebih menyukai programprogram yang ditayangkan oleh televisi berjaringan nasional karena dianggap lebih informatif dan menghibur.

Menjadi keresahan masyarakat juga adalah banyaknya penggunaan bahasa yang tidak sesuai dalam penayangan program acara pada televisi berjaringan nasional. Banyaknya penggunaan bahasa gaul ternyata berpengaruh pada penggunaan bahasa Palembang. Banyak masyarakat terutama kalangan remaja kini menggunakan bahasa Palembang yang tercampur dengan bahasa gaul dan akhirnya mengikis keaslian bahasa Palembang.

Faktor yang terakhir ialah ketidaktahuan masyarakat berpendidikan menengah tentang adanya regulasi yang mendukung pelestarian bahasa dan budaya lokal sehingga sistem kontrol sosial terhadap media tidak berjalan secara maksimal. Hal ini terlihat dari laporan yang masuk ke KPID Sumsel dalam skala 6 bulan terakhir tidak ada satu pun laporan yang terkait bahasa yang diadukan ke KPID Sumsel.

Dengan demikian, televisi lokal diharapkan menjadi saluran pelestari budaya Palembang. Kehadiran televisi yang menggunakan bahasa lokal tentunya memiliki efek pada masyarakat yang menyaksikan tayangannya. Untuk itu, dilakukan in-depth interview kepada enam orang narasumber yang telah dipilih.

\section{Acara yang Diharapkan Pemirsa belum Tersedia di Televisi Lokal}

Narasumber pertama ialah Abu Bakar As-Siddiq, seorang Pelajar kelas XI SMA. Dia cukup sering meyaksikan tayangan televisi karena statusnya sebagai pelajar yang tidak terlalu sibuk degan rutinitas harian. Dia sangat menyukai acara talkshow motivasi, 
seperti Hitam Putih di Trans 7, talkshow seperti itu tidak dapat ditemukan di PAL TV sehingga dia lebih sering menyaksikan tayangan televisi berjaringan nasional. Namun, sebagai penutur bahasa Palembang yang juga merupakan bahasa ibu yang digunakan, dia sangat senang dengan keunikan yang dimunculkan oleh PAL TV karena menggunakan kebanyakan bahasa Palembang dalam penayangan acaranya. Menurutnya, tayangan televisi bisa membantu pelestarian budaya apabila didengar secara berulang-ulang dan disampaikan dengan tayangan yang menarik "Sebenarnya aku suka nonton acara di PAL TV cuma acaranya kurang seru kalau dibandingkan dengan acara di TV semacam Trans 7. Aku suka acara Hitam Putih di Trans 7. Jadi, lebih senang nonton TV nasional," ujarnya. Dia tidak mengetahui adanya regulasi yang mengatur tentang penyelenggaraan penyiaran pada televisi lokal dan televisi berjaringan nasional. Dia tidak pernah mengkritisi penggunaan bahasa pada acara yang ditayangkan di televisi berjaringan nasional.

Seharusnya televisi lokal melihat adanya animo masyarakat yang menggemari jenis acara tertentu, seperti talkshow hitam putih di trans 7, televisi lokal dapat mengambil peluang dengan membuat acara serupa dengan kemasan yang mengangkat kearifan lokal sehingga lebih dekat dengan masyarakat. Hal itu akan menambah daya saing televisi lokal di mata masyarakat dengan acara-acara unggulan yang tidak kalah dengan acara di televisi berjaringan nasional.

\section{Efektifitas penayangan acara lokal dari televisi berjaringan nasional.}

Narasumber kedua ialah Muhammad Iqbal Hafizon, ia seorang mahasiswa semester I di sebuah universitas negeri. Ia cukup sering melihat tayangan televisi sebagai sarana hiburan dan informasi ketika waktu luang meskipun lebih suka menggunakan internet sebagai sarana utama mendapatkan informasi. Ia relatif sering menyaksikan acara PAL TV bahkan hampir setiap hari. Bahasa ibu yang ia gunakan adalah bahasa Palembang maka acara di PAL TV relatif lebih mudah dipahami. Ia memberi contoh pada tayangan acara berita kriminal berbahasa Palembang, yaitu "Grebek". Acara tersebut disajikan dengan cara yang unik dengan penyampaian yang sederhana dan santai membuat penonton merasa lebih dekat dengan informasi yang dibawakan dan mendongkrak kebanggaan terhadap bahasa Palembang.

Ia mengatakan bahwa apabila dikelola dengan baik, televisi dapat menjadi sarana 
pelestarian bahasa yang sangat efektif. Namun, ia menyayangkan PAL TV kurang dapat mengembangkan acara-acaranya sehingga kurang dapat bersaing dengan televisi berjaringan nasional. PAL TV masih memerlukan perbaikan kualitas, baik dari segi program maupun infrastruktur.

Ia merasa pelestarian bahasa lokal melalui televisi masih belum cukup karena beberapa faktor. Salah satunya adalah penayangan acara lokal kurang efektif karena ditayangkan pada waktu yang bukan merupakan waktu rutinitas aktivitas manusia sehingga terkesan hanya sebagai pemenuhan peraturan undang-undang. Acara yang diulang-ulang di televisi lokal membuat pemirsanya menjadi bosan dan akhirnya beralih ke acara di stasiun televisi lain. "Kalau pernah nonton acara lokal di stasiun televisi berjaringan nasional pas kebetulan bangun malam. Memang rata-rata acaranya itu ditayangkan di jam-jam yang kurang efektif buat ditonton, semisal jam12 malam, 1 malam, atau subuh," ujarnya.

Ia berharap stasiun televisi lebih bijak dalam menyediakan acara kepada masyarakat daerah dan mengurangi sentralisasi tayangan. Ia berharap dengan semakin banyaknya konten-konten lokal yang ditayangkan di televisi akan mengangkat budaya daerah tersebut sehingga bisa lebih bernilai sebagai khazanah budaya bangsa.

Diperlukan kesadaran dari penyedia siaran televisi untuk menyediakan acara bermuatan lokal sesuai dengan tujuan penyiaran nasional untuk memberikan pendidikan kepada masyarakat. Sebaiknya acara televise jangan terkesan sebagai pemenuhan kewajiban regulasi penyiaran.

\section{Representasi bahasa Palembang yang ditampilkan pada stasiun TV lokal.}

Narasumber ketiga ialah seorang ahli linguistik yang berprofesi sebagai dosen perguruan tinggi di kota Palembang bernama Magdad Hatim dengan tingkat pendidikan terakhir S2. Ia cukup sering menonton televisi sebagai sarana informasi dan hiburan. Ia berpendapat bahwa memang betul bahasa Palembang yang digunakan oleh PAL TV merupakan representasi dari bahasa Palembang yang digunakan masyarakat sehari-hari. Meskipun dari zaman ke zaman telah terjadi perubahan tata cara penggunaan bahasa Palembang. Bahasa Palembang yang digunakan saat ini bukanlah bahasa Palembang yang digunakan oleh kerajaan Sriwijaya ataupun kesultanan Palembang Darussalam. Namun, sudah cukup untuk dikatakan bahwa bahasa yang digunakan pada tayangan PAL TV adalah benar bahasa Palembang. "Memang diperlukan penggunaan bahasa 
daerah pada media massa. Dalam hal ini bahasa yang ditampilkan PAL TV sudah bisa mewakili bahasa Palembang yang digunakan oleh masyarakat Palembang saat ini meskipun bahasa Palembang yang asli sebenarnya sudah tidak digunakan dan mengalami perkembangan sampai saat ini," ujarnya.

Ia menyayangkan banyaknya siaran televisi yang menggunakan bahasa yang tidak sesuai sehingga berpengaruh pada penggunaan bahasa khususnya pada kalangan remaja Palembang. Ia juga resah dengan banyaknya masyarakat kalangan remaja yang mulai meninggalkan bahasa lokal itu sendiri dengan bahasa gaul yang ditampilkan di televisi. Namun, penggunaan dialek Palembang asli terkesan aneh untuk didengar, contohnya "Gua udah beken tugas, lo gimana?".

Stasiun televisi dapat digunakan sebagai alat pelestari bahasa yang sangat efektif. Hal itu tidak akan berpengaruh banyak jika hanya dilakukan oleh satu atau dua stasiun televise saja. Perlu ada sinergitas dari semua stasiun televisi lokal bukan hanya di kota Palembang, tetapi di setiap daerah di Indonesia untuk berperan aktif membuat acara yang menayangkan kearifan lokal di dalamnya.

Ia sangat senang dari awal kemunculan televise lokal hingga kini. Televisi lokal masih mempertahankan keunikannya dengan terus menampilkan acara-acara berbahasa lokal dan menampilkan sudut pandang kearifan lokal yang sangat dekat dengan masyarakat. Hal itu menurutnya dapat meningkatkan derajat budaya tersebut dan menjadi kebanggan tersendiri bagi masyarakat Palembang.

Acara favoritnya ketika menonton PAL TV adalah acara berita "Grebek" yang menampilkan berita dengan menggunakan bahasa Palembang. Berita yang ditampilkan berupa berita kriminal yang terjadi di sekitar wilayah Palembang, sayangnya aktualitas beritanya dianggap masih kalah cepat dengan stasiun televisi berjaringan nasional. Akan tetapi, PAL TV dianggap memiliki keunikan tersendiri dibandingkan televisi lain.

Apabila tidak ada peningkatan kualitas dari televisi lokal baik dari segi siaran, acara, dan infrastruktur untuk bersaing dengan stasiun televisi berjaringan nasional maka bukan tidak mungkin suatu saat nanti stasiun televisi lokal akan semakin terpinggirkan dan akhirnya ditinggalkan oleh pemirsanya. Stasiun televisi lokal harus tetap konsisten mempertahan kearifan lokal karena hal tersebut merupakan keunikan yang berbeda dari stasiun televisi lain dan memberikan daya tarik tersendiri bagi pemirsa televisi. 


\section{Pemerataan informasi antara Pusat dengan daerah.}

Narasumber keempat adalah seorang ibu rumah tangga dengan pendidikan terakhir S1 bernama Endah Rahmadhini. Ia tertarik menyaksikan acara berita nasional dan internasional di televisi berjaringan nasional. Selain itu, perlu informasi yang aktual dan stasiun televisi favorit yang menjadi pilihan untuk mendapat informasi adalah Metro TV. Sesekali ia menonton acara televisi lokal PAL TV dan acara favoritnya ialah berita daerah dan "Grebek" yang semuanya menyajikan informasi-informasi yang lebih dekat dengan sekitarnya. Berita di stasiun televisi berjaringan nasional cenderung tersentralisasi dengan berita di Jabodetabek dan pulau Jawa sehingga sangat sedikit porsi berita yang berkaitan dan terjadi di wilayah Palembang dan sekitarnya. PAL TV menjadi pilihan untuknya mendapatkan informasi yang dekat dengan keseharianya. "Butuh informasi makanya nonton acara di stasiun TV kaya Metro dan TVOne, tapi kan biasanya beritanya sedikit porsinya untuk wilayah Sumsel banyakan Jabodetabek. Jadinya, buat dapat informasi di sekitar kita pilihanya ya nonton PAL TV, biasanya saya nonton Grebek" ujarnya.

Ia merasa kalau porsi acara televisi berbahasa daerah sudah cukup baik dengan adanya PAL TV hanya perlu ditambah dengan keikutsertaan stasiun televisi lain untuk melestarikan bahasa dan kearifan lokal. Berita-berita yang ditampilkan pada stasiun televisi lokal harus lebih aktual agar tidak tertinggal dari stasiun televisi berjaringan nasional. Stasiun televisi nasional juga harus memperhatikan masyarakat daerah, karena masyarakat di daerah juga merupakan konsumen televisi yang memiliki hak mendapatkan acara berkualitas dan mendidik.

\section{Pentingnya aspek Pendidikan dan norma kesopanan pada acara televisi}

Narasumber kelima ialah Harry Yogsunandar, seorang praktisi ilmu komunikasi dengan pendidikan terakhir S2 dan saat ini berprofesi sebagai dosen. Karena, ia jarang memiliki waktu untuk menonton televisi, hanya sesekali dalam seminggu. Dia menggunakan media internet sebagai sarana utama mendapatkan informasi. Selain lebih actual, internet bisa diakses melalui gadget dan lebih praktis mendukung mobilitasnya dalam aktivitas sehari- hari.

Meskipun tidak punya banyak waktu untuk menonton televisi, sebagai praktisi ia banyak memperhatikan perkembangan media massa termasuk televisi. Menurutnya televisi dapat menjadi alat pelestari bahasa yang efektif apabila dijalankan dengan pengelolaan yang baik dan peningkatan kualitas acara siaran di televisi lokal harus progresif. Selain itu, pada televisi berjaringan nasional juga diperlukan penempatan jam 
siaran yang tepat karena semua stasiun televisi berjaringan nasional memiliki acara bermuatan lokal sesuai dengan peraturan KPI. Hal itu tidak akan efektif jika ditayangkan di jam-jam yang tidak tepat, seperti dini hari atau tengah malam.

Selain itu, dampak yang ditimbulkan oleh televisi akan lebih terlihat kepada orang- orang yang memiliki intensitas kesibukan yang tidak terlalu tinggi sehingga memiliki banyak waktu luang untuk menonton televisi seperti pelajar, mahasiswa, dan karyawan. Akan tetapi, mereka yang memiliki intensitas kesibukan tinggi tidak akan terlalu terpengaruh oleh siaran televisi karena tidak memiliki banyak waktu untuk menonton televisi.

Ia melihat begitu banyak permasalahan yang perlu dibenahi pada televisi berjaringan nasional dan lokal. Mulai dari penggunaan bahasa yang tidak sesuai pada beberapa acara televisi berjaringan nasional yang justru membuat fungsi televisi untuk membantu memahami bahasa Indonesia yang baik dan benar kurang terlaksana. Sentralisasi acara televisi yang terpusat di Jabodetabek terjadi di hampir semua stasiun televisi. Maksudnya adalah bahwa stasiun televisi cenderung mengutamakan informasi yang terjadi di Jabodetabek dan sekitarnya. Bahkan azan pun ditayangkan serentak menggunakan jadwal azan untuk DKI Jakarta dan sekitarnya. Padahal waktu azan antara Jabodetabek dengan daerah lain berbeda. "Ya, stasiun TV harusnya juga punya standar penggunaan bahasanya. Jadi, fungsi pendidikan jalan. Karena ada penggunaan bahasa, semisal bahasa pasar kan bakalan beda dengan penggunaan bahasa yang dipakai sama cendekiawan? Maka itu perlu adanya pengetahuan dari stasiun televisi terkait hal itu, artisnya juga mesti di-training agar menggunakan bahasa yang baik dan benar juga sopan," ujarnya.

Itu merupakan sebagian dari permasalahan televisi lokal berjaringan nasional yang bersiaran di kota Palembang. Namun, masalah juga terjadi pada stasiun televisi lokal sebagai penyedia konten dan acara kedaerahan. Memang bahasa yang ditampilkan merupakan representasi bahasa Palembang yang digunakan oleh masyarakat Palembang, Akan tetapi, dalam kelompok masyarakat penggunaan bahasa pasti memiliki tingkatantingkatan tertentu mulai kelas menengah ke bawah hingga penggunaan bahasa oleh kalangan cendekiawan dan agamawan pastilah berbeda satu sama lain.

Menurut budayawan Palembang, Vebri Al-Lintani dalam sebuah kesempatan wawancara mengatakan bahwa bahasa Palembang memiliki beberapa jenis cara penuturan yang seperti dalam bahasa Jawa disebut kromo dan ngoko maka di Palembang 
terdapat bahasa Palembang dengan penuturan halus, yaitu bebaso dan bahasa dengan penuturan kasar, yaitu baso sari-sari. Dalam penayangan siarannya kebanyakan penggunaan bahasa di acara-acara PAL TV ialah baso sari-sari terutama di acara komedi Studio 42. Hal itu harus menjadi perhatian televisi lokal untuk mengoreksi diri. Apakah bahasa yang ditampilkan oleh mereka merupakan bahasa yang baik dan mendidik atau hanya sekadar mengangkat bahasa lokal, tetapi tidak memperhatikan aspek pendidikan dan wibawa bahasa itu sendiri.

Masalah lainnya ialah kualitas siaran televisi lokal yang masih jauh bila dibandingkan dengan televisi berjaringan nasional, pemirsa televisi adalah konsumen. Sebagai penyedia layanan televisi lokal semestinya memberikan siaran yang menarik agar pemirsanya tidak bosan. Namun, ia meyakini bahwa televisi lokal masih memiliki banyak peminat terbukti dengan masih banyak iklan yang menjadi sumber operasional televisi menunjukan acara televisi lokal masih memiliki statistik rating yang cukup tinggi.

Proses penyiaran stasiun televisi lokal dan berjaringan nasional masih harus banyak berbenah menata siarannya agar sesuai dengan tujuan awal dari penyelenggaraan penyiaran. Seluruh komponen media ikut menyukseskan pelestarian bahasa lokal dengan mendukung penyediaan siaran berbahasa lokal dengan tetap mengedepankan aspek pendidikan dan norma kesopanan dalam penyelenggaraan penyiaran. Seperti dalam memperhatikan kualitas sang artis agar apapun bentuk yang mereka tampilkan dapat memberikan efek pendidikan kepada masyarakat.

\section{Pengaruh pemilihan bahasa yang digunakan oleh stasiun televisi}

Narasumber keenam bernama Retna Mahriani. Seorang dosen Ilmu Komunikasi dengan pendidikan terakhir S3. Menurutnya, televisi adalah suatu kebutuhan untuk mendapatkan hiburan dan informasi. Karena kebutuhan akan informasi di sekitar dan informasi tentang pemerintahan, TVone dan Metro TV menjadi pilihan utama untuk mendapatkan informasi. Menurutnya televisi memiliki kemampuan untuk memberikan pendidikan termasuk di antaranya pendidikan bahasa Indonesia. Namun, itu semua tergantung dari acara yang disiarkan. Jika salah memilih acara, tidak akan dapat merasakan fungsi tersebut dan malah akan mengacaukan penggunaan bahasa.

Dewasa ini bahasa yang ditampilkan oleh televisi dianggap sebagai pembenaran dan penggunaannya dianggap paling benar sehingga banyak dicontoh oleh masyarakat, terutama kalangan remaja. Padahal banyak terjadi kesalahan penggunaan bahasa oleh 
media televise dalam berbagai siaran. "Kita lihat contohnya semisal sekarang di Palembang banyak stasiun radio penyiarnya pakai kata elo dan gua padahal itu kan tidak sesuai sama bahasa kita. Jadi, pengaruh pemilihan bahasa itu penting karena orang awam akan menganggap penggunaan bahasa yang ditampilkan oleh media massa itu sebagai pembenaran bahwa ini lho bahasa yang harusnya kita pakai, gitu," ujarnya.

Hadirnya televisi lokal berbahasa Palembang menurutnya dapat menjadi alat untuk pelestarian bahasa, baik bahasa Indonesia maupun bahasa lokal. Namun, sangat disayangkan bahwa penggunaan fungsi pendidikan tersebut tidak dijalankan dengan maksimal. Selain kesibukannya sebagai seorang dosen, tidak memiliki banyak waktu untuk melihat tayangan televisi apalagi siaran acara yang mengangkat bahasa dan kearifan lokal yang porsinya sangat sedikit dan ditayangkan di jam-jam yang sulit dijangkau masyarakat, seperti tayangan budaya yang ditayangkan dini hari. Akhirnya, tayangan televisi itu hanya memiliki efek kognitif karena hanya dilihat sekilas dan situasional.

Kesibukannya membuat ia tidak memiliki banyak waktu untuk menonton tayangan televisi. Namun, sesekali PAL TV menjadi pilihan penonton meskipun frekuensinya tidak sebanyak stasiun televisi lain. Ia sering menonton PAL TV ketika bulan ramadhan, alasannya karena PAL TV menayangkan acara kerohanian dibalut dengan muatan lokal dan juga menunggu azan di mana kumandang adzan maghrib di PAL TV sesuai dengan jadwal azan kota Palembang.

Ia menyukai acara "Grebek" di PAL TV selain karena kebutuhan akan informasi juga karena "Grebek" memiliki keunikan tersendiri yaitu mengangkat informasi yang dekat dengan masyarakat menggunakan bahasa lokal yang digunakan oleh masyarakat sehari-hari. Aktualitas berita PAL TV masih kurang bila dibandingkan dengan stasiun televisi berjaringan nasional dan sering kali berita yang sama diulang-ulang dalam sehari.

Meskipun penguasaan bahasa Palembang lebih utama ia rasakan, didapatkan dari interaksi dengan masyarakat sekitar dan interaksi dengan keluarga. Akan tetapi, ia melihat bahwa televisi lokal dapat menjadi harapan untuk pelestarian bahasa lokal yang mulai tersingkir oleh penggunaan bahasa yang sudah bercampur dengan bahasa gaul yang tidak sesuai dengan kaidah penggunaan bahasa Indonesia yang benar.

Hal itu dapat terlaksana apabila stasiun televisi lokal tetap konsisten memberikan tayangan yang mendidik dan mengedepankan aspek edukasi dan kualitas acara. Hal itu nantinya akan membangkitkan kebanggaan bagi masyarakat untuk mengedepankan 
bahasa lokalnya sendiri. Karena memiliki stasiun televisi yang mengutamakan pendidikan dan kebudayaan, suatu kebanggaan tersendiri dan memberi harapan pada keberlangsungan penggunaan bahasa lokal Palembang.

Menurutnya porsi acara yang mengangkat bahasa dan kearifan perlu ditambah karena masih belum cukup, tidak hanya sekadar acara yang berbahasa lokal, tetapi acara yang mengkhususkan pada pendidikan bahasa baik bahasa Indonesia maupun bahasa lokal. Ia berharap para pemilik media dan pemerintah harus memikirkan aspek pendidikan dan pembawa acaranya harus banyak dilatih. Apabila dirawat dan diarahkan dengan baik, media akan menjadi sarana yang ampuh untuk mendidik masyarakat, terutama dalam hal penggunaan bahasa.

\section{Pelestarian bahasa daerah dilihat dari perspektif budayawan Palembang}

Ketua dewan kesenian Palembang Vebri Al-Lintani dalam kesempatan wawancaranya mengemukakan pandanganya mengenai pelestarian bahasa Palembang, terutama yang berhubungan dengan peran televise. Dia menganggap televisi merupakan sebuah sarana strategis dalam pelestarian bahasa, meskipun televisi berbahasa lokal baru muncul di era belakangan ini. Namun, akan sangat berdampak apabila porsinya ditingkatkan dan dikurangi kesalahan dalam tata bahasa yang digunakan oleh televisi lokal

Bahasa Palembang memiliki beberapa jenis cara penuturan yang seperti dalam bahasa Jawa disebut kromo dan ngoko, maka di Palembang terdapat bahasa Palembang dengan penuturan halus yaitu bebaso dan bahasa dengan penuturan kasar, yaitu baso sari-sari. Dalam penayangan siaranya kebanyakan penggunaan bahasa di acara-acara PAL TV ialah baso sari-sari terutama di acara komedi Studio 42, masyarakat Palembang sendiri kini lebih sering menggunakan baso sari-sari. Sementara itu, bebaso kini hanya digunakan oleh masyarakat beretnis asli Palembang dan keturunan keraton Palembang.

Ada istilah dalam bahasa Palembang yaitu baso nunjukke bangso yang artinya bahasa yang digunakan oleh kita menunjukan kebanggaan kita terhadap identitas diri. Namun, dengan adanya percampuran bahasa seperti yang sekarang terjadi pada kalangan remaja Palembang menimbulkan adanya indikasi kehilangan identitas. Untuk itu, media harus mempelajari bahasa secara baik bukan hanya demi keperluan untuk mencari keuntungan perusahaan, tetapi juga untuk pendidikan. Karena kesalahan dalam penggunaan bahasa yang ditampilkan oleh media, dapat berakibat rusaknya struktur tata bahasa yang baik dan benar. 


\section{SIMPULAN}

Regulasi tentang penyiaran tertuang dalam UU No. 32 Tahun 2002 tentang penyiaran dan juga Pedoman Perilaku Penyiaran dan Standar Program Siaran (P3SPS). Regulasi ini bertujuan untuk menjaga agar penyelenggaraan penyiaran tetap berjalan sesuai dengan semestinya. Pada beberapa poin dalam peraturan tersebut dibuat untuk menjaga hak konsumen media di daerah agar tetap mendapatkan porsi pendidikan yang ditayangkan oleh televisi dengan mempertahankan bahasa dan kearifan lokal masyarakat setempat. Namun, fungsi-fungsi tersebut menjadi kurang efektif ketika faktanya penyelenggaraan penyiaran di daerah hanya terkesan sebagai pemenenuhan kewajiban terhadap regulasi pemerintah.

Dengan faktor-faktor yang telah dikemukakan dapat disimpulkan bahwa stasiun televisi berjaringan nasional belum menjalankan fungsi edukasi dan pelestarian bahasa sebagaimana mestinya. Hingga saat ini tingkat pelestarian bahasa lokal pada televisi berjaringan nasional masih rendah, padahal seperti yang telah dibahas stasiun televisi memiliki andil yang sangat besar dalam pelestarian dan penyebarluasan bahasa. Kekurangan televisi berjaringan ini sedikit tertutupi dengan hadirnya televisi lokal seperti PAL TV.

Televisi dapat menjadi sarana strategis dalam pelestarian bahasa dengan pengelolaan yang baik berupa penambahan acara yang beragam dan sesuai dengan minat masyarakat. Hal itu untuk menarik perhatian penonton, tentu dengan tetap mengemas acara tersebut dengan sentuhan kearifan lokal. Penggunaan bahasa lokal yang massif di televisi dapat menimbulkan rasa bangga dan percaya diri untuk menggunakan bahasa lokal dan memperkenalkanya ke ranah nasional.

Televisi lokal harus menjadi yang terdepan dalam pelestarian bahasa diiringi dengan televisi berjaringan nasional. Penayangan acara lokal yang masih sedikit dan ditayangkan di waktu-waktu yang kurang utama membuat televisi lokal berjaringan nasional dalam menjalankan fungsi budaya kurang berjalan dengan maksimal. Untuk itu, stasiun televisi lokal berjaringan nasional perlu menumbuhkan kesadaran untuk memberikan tayangan yang tidak hanya sekadar untuk mematuhi regulasi, tetapi juga ikut menjalankan fungsi budaya pada siaran televisinya. 


\section{DAFTAR PUSTAKA}

Alwi, Hasan. (2002). Kamus Besar Bahasa Indonesia. Jakarta: Balai Pustaka.

Budiwiyanto, Adi. (2016) "Pendokumentasian Bahasa dalam Upaya Revitalisasi Bahasa Daerah yang Terancam Punah di Indonesia". Diakses tanggal 06 Oktober 2016. http:// badan-bahasa.kemdikbud.go.id/lamanbahasa/artikel/1823.

Bungin, Burhan. (2006). Sosiologi Komunikasi: Teori, Paradigma, dan Diskurusus Teknologi Komunikasi di Masyarakat. Jakarta: Fajar Interprtatama Mandiri.

Dominick, Joseph R. (2011). McGraw-Hill Education. Manfaat.co.id. 2016 "Manfaat Televisi bagi Masyarakat" http://manfaat.co.id/manfaattelevisi-bagi-masyarakat.

Mulyana, Deddy. (2014) Ilmu Komunikasi: Suatu Pengantar. Cetakan ke 18. Bandung: PT. Remaja Rosdakarya.

Paltv.co.id. (2016). "Jadwal acara". Diakses tanggal 06 Oktober 2016. http://paltv.co.id/online/ jadwal-acara/

Purnama, Imma. (2016). "Inilah 9 Penjelasan Manfaat Menonton Televisi yang Perlu Kamu Tahu". Diakses tanggal 06 Oktober 2016. http://papasemar.com/inilah-9penjelasanmanfaat-menonton-televisi-yang-perlu-kamu-tahu/

Sugiarsih, Septia. (2016). "Hakikat dan Fungsi Bahasa". Diakses tanggal 06 November 2016. 